\title{
Evaluating CDOM Sources Using Excitation-Emission Matrix Fluorescence and Parallel Factor Analysis, and their Links to Water Quality in Highly Polluted Rivers in China
}

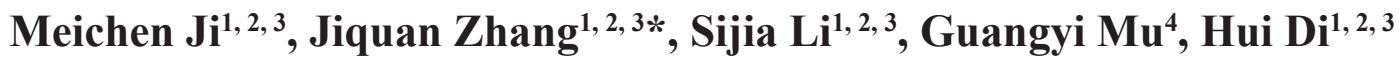

${ }^{1}$ School of Environment, Institute of Natural Disaster Research, Northeast Normal University, Changchun, China

${ }^{2}$ Key Laboratory for Vegetation Ecology, Ministry of Education, Changchun, China

${ }^{3}$ State Environmental Protection Key Laboratory of Wetland Ecology and Vegetation Restoration, Northeast Normal University, Changchun, China

${ }^{4}$ School of Life Science, Institute of Grass Science, Northeast Normal University, Changchun, China

Received: 15 January 2018

Accepted: 28 February 2018

\begin{abstract}
Chromophoric dissolved organic matter (CDOM) is a valuable optically active substance. This study examined the seasonal characteristics of fluorescent CDOM components in the Yinma and Songhua rivers, highly polluted watershed tributaries of the Songhua River, and a drinking water source for the city of Changchun, China. Parallel factor analysis (PARAFAC) and excitation-emission matrix (EEM) spectra were used to assess CDOM fluorescence. Four components attributed to CDOM in 51 water samples were identified: three were humic-like $(\mathrm{C} 1, \mathrm{C} 3$, and $\mathrm{C} 4)$ and one was protein-like $(\mathrm{C} 2)$. The average fluorescence intensities of the four components showed seasonal variation from May to November 2016. A positive linear correlation was found between components $\mathrm{C} 3$ and $\mathrm{C} 4(R=0.86$, $p<0.001)$. The results from this investigation demonstrated that the frequency of rainfall and human activities may be the main factors influencing the quantity and quality of CDOM in samples collected from the watershed, and that the Yinma and Yitong rivers were polluted by terrestrial and agricultural pollution. Furthermore, the utility of combining EEM fluorescence and PARAFAC to study CDOM dynamics for different seasons and to quantify CDOM components for similar environmental (water quality) conditions was established.
\end{abstract}

Keywords: chromophoric dissolved organic matter, fluorescence, PARAFAC, water quality parameters, excitation-emission matrix

*e-mail: zhangjq022@nenu.edu.cn 


\section{Introduction}

Chromophoric dissolved organic matter (CDOM) is the coloured component of dissolved organic matter (DOM) in natural waters. CDOM is principally contributed by surrounding terrestrial inputs (allochthonous sources) and degradation of plant materials (allochthonous sources) by microorganisms. Additionally, river discharge consists of a varied mixture of aliphatic and aromatic polymers [1]. The photochemical and microbial transformation processed by algae, bacteria, or plants play a vital role in global carbon cycling dynamics [2]. More importantly, CDOM absorbs light energy in the ultraviolet (UV) spectrum in order to shield biota from harmful UV radiation, and also affects the transport and bioavailability of materials such as trace metals and organic substances [3]. Some optically active components of CDOM can emit fluorescence after absorbing light at certain wavelengths [4]. Therefore, fluorescence spectroscopic techniques can be used to provide detailed information about the sources and composition of CDOM.

Absorption and fluorescence spectral analysis of $\mathrm{CDOM}$ has been used to trace its origin as well as chemical composition [5], and is used as an indicator of water quality. The absorption of CDOM at a special wavelength is commonly used to quantify the CDOM concentration [6]. Different absorption and fluorescence parameters reflect the variations in CDOM composition from several autochthonous or allochthonous sources. Fluorescence spectroscopy using excitation-emission matrices (EEMs) is dependent on the wavelength of the emitted and excited radiation and is a highly selective and sensitive method for characterizing CDOM in various water masses due to its ability to produce synchronous scan spectra in the form of contours [7]. EEM spectroscopy has been widely used to study the dynamics of marine, freshwater, and ice melt water ecosystems as well as snowmelt water [8-10]. However, overlapped fluorophores of CDOM EEM could make this traditional 'peak-picking' method unreliable for evaluating CDOM dynamics in aquatic ecosystems [10]. Recently, the combined EEM-PARAFAC (parallel factor analysis) technique has been widely used to characterise DOM in inland and marine aquatic environments $[4,8$, 12]. It could effectively decompose EEMs of CDOM into independent fluorescent components and confirm the sources of CDOM. The EEM-PARAFAC technique identified four distinct CDOM components for lakes in the semiarid regions of northeastern China [13]. In Lake Taihu and its tributaries, five components as well as the abundance of chromophoric components using the EEM-PARAFAC technique were found, and the correlations between fluorescent components and absorption coefficients of CDOM were analysed [12]. Zhou et al. decomposed CDOM fluorescence into six components by PARAFAC modelling and used the optimal wavelength derived from CDOM fluorescence to trace point-source contamination in drinking water [13].

To date, there have been a few uses of CDOM fluorescence for investigating and monitoring water quality in natural lakes, rivers, and reservoirs. CDOM could present different fluorescence intensities for highly polluted rivers affected by human activities due to their different and complex compositions and sources. This study uses the EEM-PARAFAC model to understand seasonal sources and variations of CDOM in the Yinma and Yitong rivers, which were the most polluted tributaries of Songhua River, China [14]. As typical contaminated rivers in northeastern China, the pollution status of the Yinma and Yitong is serious, especially since the chemical explosion in Jilin in 2005. The results of this study could effectively help us understand and manage aquatic resources as well as maintain their health. In this study, CDOM in the Yinma and Yitong were investigated with the following objectives: 1) to describe the distribution characteristics of CDOM and water quality parameters, 2) to characterise CDOM components and their origins by the EEM-PARAFAC, and 3) to assess the relationships between EEMPARAFAC and water quality concentrations associated with watershed landscapes.

\section{Material and Methods}

\section{Study Sites and Water Sampling}

The Yinma and Yitong, as second tributaries of the Songhua River, are located in the middle of Jilin Province (Fig. 1). The Yinma and Yitong are $386.8 \mathrm{~km}$ and $343.5 \mathrm{~km}$ long, respectively, and the average water surface area is $94.2 \mathrm{~km}^{2}$, with a capacity of 702 million $\mathrm{m}^{3}$ and an average depth of $3.3 \mathrm{~m}$. In the Yinma River Basin, cultivated land accounts for about $70 \%$ of land use type and the urbanisation rate is $68.4 \%$. Additionally, the Yinma River Basin is both the primary domestic and irrigation water source for the surrounding area. The Yinma is located in a region that experiences a temperate continental monsoon climate. The wind is large in spring, rainy warm in summer, and there is a large temperature difference in autumn and a long cold winter. The average temperature is $4.9^{\circ} \mathrm{C}$ and annual precipitation ranges from $329.7 \mathrm{~mm}$ to $866.6 \mathrm{~mm}$, with an annual average of $580 \mathrm{~mm}$. In this basin, the east is the transition zone of mountains and Songliao Plain, the south is low hills, the northwest is Songliao Plain, and the central is a plain. The southeast and northwest are characterised by high and low terrain, respectively. The main tributaries of the Yinma from upstream to downstream include the Shuangyang, Chalu, Xiaonan, Wukai, and Yitong rivers. The main reservoirs include Shitou Koumen, Xinlicheng, and Xingxingshao. The total water resource is 2.472 billion $\mathrm{m}^{3}$, and the per capita water resource of $378 \mathrm{~m}^{3}$ accounts for $18 \%$ of the total national value for China [15]. 


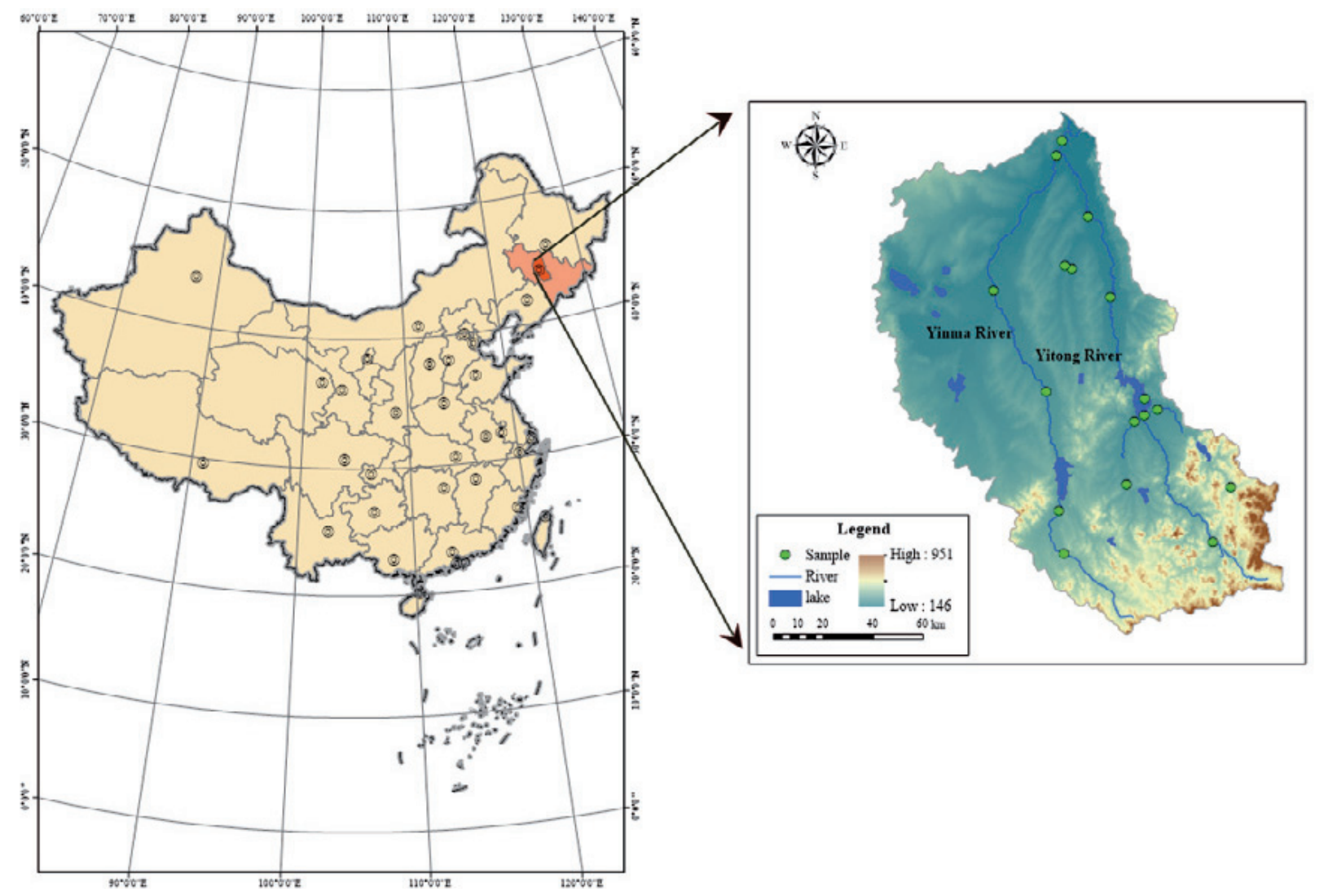

Fig. 1. Sampling sites in Yinma and Yitong rivers.

\section{Water Quality Determination}

In this study, a total of 51 samples were collected from 17 sites across the Yinma and Yitong on 15 May, 27 August, and 2 November 2016. The water sampling monitoring point was fixed (the data for May and August 2016 are found in [14]). The water samples were collected from the surface at each location at a depth of $0-0.2 \mathrm{~m}$. The samples were stored at $4^{\circ} \mathrm{C}$ in cooler boxes until further analysis to be conducted within the next two days. Samples were analysed for dissolved organic carbon (DOC), chlorophyll-a (Chl-a), total nitrogen (TN), total phosphorous (TP), hexavalent chromium $\left(\mathrm{Cr}^{6+}\right)$, and ammonia nitrogen $\left(\mathrm{NH}_{3}-\mathrm{N}\right)$. To determine DOC concentrations, all water samples were filtered through a pre-combusted Whatman GF/F (1825-047) filter $(0.45 \mu \mathrm{m})$ under conditions of low vacuum. The DOC concentrations were determined by Shimadzu, TOC-VCPN. The Chl-a concentrations were determined with a UV spectrophotometer (Shimadzu, UV-2006 PC) and the detailed descriptions are available in Song et al. [16]. According to the National Standard of Environmental Quality GB38382002, TN and TP were measured by the spectrophotometric method; hexavalent chromium $\left(\mathrm{Cr}^{6+}\right)$ was measured by the diphenylcarbohydrazide spectrophotometric method and ammonia nitrogen $\left(\mathrm{NH}_{3}-\mathrm{N}\right)$ was determined by Nessler's reagent colorimetry, while chemical oxygen demand (COD) was measured by dichromate.

\section{CDOM Absorption Measurement}

In the laboratory, all water samples were filtered under low vacuum conditions through a pre-combusted Whatman GF/F filter $(0.7 \mu \mathrm{m})$. Subsequently, the filtered samples were passed through a premised $25 \mathrm{~mm}$ Millipore cellulose filter $(0.22 \mu \mathrm{m})$ into brown glass bottles. CDOM absorption spectral was measured between $200 \mathrm{~nm}$ and $800 \mathrm{~nm}$ at $1 \mathrm{~nm}$ increments using a Shimadzu UV-2600 spectrophotometer. Milli-Q water was used as a reference.

The uncorrected absorption coefficient $\alpha_{\text {CDOM }}\left(\lambda^{\prime}\right)$ was calculated from the measured optical density (OD) of the sample using Equation (1):

$$
\alpha_{\mathrm{CDOM}}\left(\lambda^{\prime}\right)=\frac{2.3030 \mathrm{D}(\lambda)}{\gamma}
$$

...where $\gamma$ is the cuvette path length $(0.01 \mathrm{~m})$ and 2.303 is the conversion factor [17]. $\mathrm{OD}(\lambda)$ is the optical density at the same wavelength [17-18].

Some fine particles and colloids possibly remained in the filtered solution and necessitated correction based on the following Equation (2):

$$
\alpha_{\text {CDOM }}(\lambda)=\alpha_{C D O M}\left(\lambda^{\prime}\right)-\alpha_{C D O M}\left(750^{\prime}\right)\left(\frac{\lambda}{750}\right)
$$


...where $\alpha_{\text {CDOM }}(\lambda)$ is the corrected absorption coefficient by scattering at wavelength $\lambda$, and $\alpha_{\mathrm{CDOM}}\left(750^{\prime}\right)$ is the uncorrected absorption coefficient at $750 \mathrm{~nm}$.

A CDOM absorption spectrum could use exponential function for expression as the following Equation (3) [17]:

$$
\alpha_{\mathrm{CDOM}}\left(\lambda_{i}\right)=\alpha_{\mathrm{CDOM}}\left(\lambda_{0}\right) \exp \left[-S\left(\lambda_{i}-\lambda_{0}\right)\right]
$$

...where $\alpha_{\mathrm{CDOM}}\left(\lambda_{i}\right)$ is the CDOM absorption at a given wavelength $\lambda_{i}$ and $\alpha_{\mathrm{CDOM}}\left(\lambda_{0}\right)$ is the absorption at the reference wavelength $\lambda_{0}(440 \mathrm{~nm}) . S$ is the CDOM spectral slope of CDOM absorption. $S_{275-295}$ and $S_{350-400}$ were calculated from the data using a linear model over spectral ranges of 275-295 $\mathrm{nm}(S 1)$ and 350-400 nm $\left(S_{2}\right)$. Subsequently, $S_{\mathrm{R}}=S_{1} / S_{2}$ was estimated. SUVA $_{254}$ was calculated by dividing the UV absorbance at $254 \mathrm{~nm}$ by the DOC concentration $\left(\mathrm{mg} \mathrm{L}^{-1}\right)$ [19].

\section{Fluorescence Measurements and PARAFAC Modelling}

EEM provides information about DOM, which is a complex mixture with fluorescence signals that are difficult to interpret. A three-way PARAFAC technique is not only a valuable tool to decompose the CDOM fluorescence signal into separate fluorescent signals, but it also provides both quantitative and qualitative models for the data.

The PARAFAC models' three-way data and residual array using Equation (4) [20]:

$$
\begin{gathered}
\chi_{i j k}=\sum_{f=1}^{F} a_{i f} b_{j f} c_{k f}+e_{i j k} i=1,2, \ldots, I j \\
=1,2, \ldots, J k=1,2, \ldots, K
\end{gathered}
$$

... where $\chi_{i j k}$ is the fluorescenceintensity of the $i^{t h}$ sample measured at emission wavelength $j$ and excitation wavelength $k$. The model parameters (i.e., $a, b$ and c) represent the concentration, emission spectra, and excitation spectra of the underlying fluorescence, respectively. $e_{i j k}$ represents the residuals representing noise and other un-modelled variation not accounted for by the model.

Before implementing PARAFAC modelling, poorquality wavelength ranges were removed due to the effect of Rayleigh scatter on PARAFAC modelling, where the excitation wavelengths range from 200 to $220 \mathrm{~nm}$ and the emission wavelengths from 250 to $350 \mathrm{~nm}$, and the region of the spectra is influenced by scatter peaks $(E \mathrm{x}-40 \leq E \mathrm{~m} \leq E \mathrm{x}+40$ and $2 E \mathrm{x}-40 \leq E \mathrm{~m} \leq$ $2 E \mathrm{x}+40)$, in order to confirm the appropriate numbers of PARAFAC components.

\section{Statistical Analyses}

The statistical analyses were performed using SPSS 16.0 software to examine the relationships between water quality parameters and maximum fluorescence intensities. Regression and correlation analyses were conducted and significance was determined at a $p$-value of 0.05 . Statistical differences between indices were assessed with an independent samples $t$-test. A difference was regarded as statistically significant when $p$-values were less than or equal to 0.05 .

\section{Results and Discussion}

\section{Water Quality}

The water quality parameters of the 51 water samples collected in spring (May), summer (August), and winter (November) are shown in Table 1. The water body was divided into five classes (Class I to Class $\mathrm{V}$; in accordance with the National Quality Standard for Surface water, China (GB3838-2002)) to represent an increasing concentration range of pollutants in the samples. The average concentrations of COD, TN, TP, $\mathrm{NH}_{3}-\mathrm{N}$, and $\mathrm{Cr}^{6+}$ in the Yinma and Yitong, pooled for all the water samples, exceeded the GB3838-2002 standard guideline levels for Classes II, III, II, and I, respectively, and these results are consistent with $\mathrm{Li}$ et al. [14, 21]. Seasonal average DOC concentrations exhibited higher values in August (31.33 mg L-1) than in May (17.3 $\left.\mathrm{mg} \mathrm{L}^{-1}\right)$ and November (16.12 mg $\mathrm{L}^{-1}$ ), while Chl-a concentrations showed a consistent seasonal tendency (Tab. 1). Generally, DOC concentrations exhibited higher values than those of 30 rivers in the U.S. [22], where the DOC levels ranged from $1.0 \mathrm{mg} \mathrm{L}^{-1}(0.4 \pm \mathrm{SD})$ in Lookout Creek to $42.1 \mathrm{mg} \mathrm{L}^{-1}(16.0 \pm \mathrm{SD})$ in St. Marys. On the contrary, a few previous studies showed high DOC levels in Arctic rivers during the snowmelt period. Although meteorological processes are generally not known to affect DOC concentrations, hydrologic processes impact DOC concentrations [23-25]. Rainfall could bring more terrestrial organic matter into the rivers by erosion. However, higher DOC consistent with high Chl-a and nutrient concentrations found in August indicate that during summer DOC was influenced by terrestrial inputs, phytoplankton, and human activities.

Chl-a concentrations showed higher levels than those reported for other rivers by previous studies, particularly in August. This is related to increased temperature and activity of microorganisms during summer. Inversely, increased $\mathrm{TN}, \mathrm{NH}_{3}-\mathrm{N}$, and $\mathrm{TP}$ concentrations found in November were due to the decreased dilution effect by precipitation (Table 1). This eutrophic status was associated with agricultural nonpoint source pollution and point source pollution by the basin. COD could be used as a comprehensive indicator of organic content in the water. Higher average COD concentrations were shown in May $\left(66.32 \mathrm{mg} \mathrm{L}^{-1}\right)$ and November (62.43 $\mathrm{mg} \mathrm{L}^{-1}$ ) than in August (17.67 $\mathrm{mg} \mathrm{L}^{-1}$ ), indicating more organic pollution. $\mathrm{Cr}^{6+}$ is a toxic heavy 
Table 1. Average values of water parameters in different seasons for all samples.

\begin{tabular}{|c|c|c|c|c|c|c|}
\hline Time & \multirow{2}{*}{ GB3838-2002 } & & May & August & November & All \\
\hline $\mathrm{N}$ & & & 17 & 17 & 17 & 51 \\
\hline \multirow{3}{*}{ DOC } & \multirow{3}{*}{ - } & Min & 9.73 & 16.62 & 8.18 & 8.18 \\
\hline & & Max & 32.47 & 69.79 & 35.17 & 69.79 \\
\hline & & Ave & 17.3 & 31.33 & 16.12 & 21.61 \\
\hline \multirow{3}{*}{ Chl-a } & \multirow{3}{*}{ - } & Min & 1.18 & 6.05 & 18.59 & 1.18 \\
\hline & & Max & 61.68 & 96.53 & 65.82 & 96.53 \\
\hline & & Ave & 11.47 & 84.74 & 42.28 & 46.16 \\
\hline \multirow{3}{*}{ COD } & \multirow{3}{*}{40} & Min & 16.36 & 2.05 & 8.06 & 2.05 \\
\hline & & Max & 68.99 & 31.31 & 65.01 & 68.99 \\
\hline & & Ave & 66.32 & 17.67 & 62.43 & 48.8 \\
\hline \multirow{3}{*}{$\mathrm{NH}_{3}-\mathrm{N}$} & \multirow{3}{*}{2.0} & Min & 0.18 & 0.00 & 0.02 & 0.00 \\
\hline & & Max & 0.24 & 0.92 & 0.77 & 0.92 \\
\hline & & Ave & 0.20 & 0.31 & 0.23 & 0.25 \\
\hline \multirow{3}{*}{$\mathrm{TN}$} & \multirow{3}{*}{0.2} & Min & 0.01 & 0.08 & 0.12 & 0.01 \\
\hline & & Max & 0.42 & 0.69 & 0.43 & 0.69 \\
\hline & & Ave & 0.19 & 0.25 & 0.26 & 0.24 \\
\hline \multirow{3}{*}{$\mathrm{TP}$} & \multirow{3}{*}{0.1} & Min & 0.017 & 0.024 & 0.021 & 0.017 \\
\hline & & Max & 0.295 & 0.248 & 0.344 & 0.344 \\
\hline & & Ave & 0.086 & 0.070 & 0.092 & 0.08 \\
\hline \multirow{3}{*}{$\mathrm{Cr}^{6+}$} & \multirow{3}{*}{0.01} & Min & 0.000 & 0.000 & 0.000 & 0.000 \\
\hline & & Max & 0.014 & 0.018 & 0.007 & 0.018 \\
\hline & & Ave & 0.003 & 0.006 & 0.003 & 0.004 \\
\hline
\end{tabular}

The units of $\mathrm{NH}_{3}-\mathrm{N}, \mathrm{COD}, \mathrm{Cr}^{6+}$, TN, TP and DOC are $\mathrm{mg} / \mathrm{L}$, and Chl-a is $\mu \mathrm{g} \mathrm{\textrm {L } ^ { - 1 }}$. N represents the numbers of samplings. Water quality standard I grade, $\mathrm{COD} \leq 15, \mathrm{NH}_{3}-\mathrm{N} \leq 0.15, \mathrm{TN} \leq 0.2, \mathrm{TP} \leq 0.02$ and $\mathrm{Cr}^{6+} \leq 0.01$; Water quality standard II grade, $\mathrm{COD} \leq 15, \mathrm{NH}_{3}-\mathrm{N} \leq 0.5, \mathrm{TN} \leq 0.5, \mathrm{TP} \leq 0.1$ and $\mathrm{Cr}^{6+} \leq 0.05$; Water quality standard III grade, $\mathrm{COD} \leq 20, \mathrm{NH}_{3}-\mathrm{N} \leq 1.0, \mathrm{TN} \leq 1.0, \mathrm{TP} \leq 0.2$ and $\mathrm{Cr}^{6+} \leq 0.05$; Water quality standard IV grade, $\mathrm{COD} \leq 30, \mathrm{NH}_{3}-\mathrm{N} \leq 1.5, \mathrm{TN} \leq 1.5, \mathrm{TP} \leq 0.3$ and $\mathrm{Cr}^{6+} \leq 0.05$; Water quality standard V grade, $\mathrm{COD} \leq 40, \mathrm{NH}_{3}-\mathrm{N} \leq 2.0, \mathrm{TN} \leq 2.0, \mathrm{TP} \leq 0.4$ and $\mathrm{Cr}^{6+} \leq 0.1$.

metal contaminant prevalent in contaminated water bodies. Higher average $\mathrm{Cr}^{6+}$ concentrations were shown in August $\left(0.006 \mathrm{mg} \mathrm{L}^{-1}\right)$ than in May $\left(0.003 \mathrm{mg} \mathrm{L}^{-1}\right)$ and November $\left(0.003 \mathrm{mg} \mathrm{L}^{-1}\right)$. Additionally, the values of $\mathrm{Cr}^{6+}$ during the three months were lower than $0.01 \mathrm{mg} \mathrm{L}^{-1}$, indicating that the river was not polluted by $\mathrm{Cr}^{6+}$.

\section{CDOM Absorption Characteristics}

The CDOM absorption parameters presented significant variations due to the hydrological, climatic, and landscape inputs, etc. The absorption coefficient at $254 \mathrm{~nm}\left[\alpha_{\mathrm{CDOM}}(254)\right]$ is generally used in tracing dissolved aromatic carbon content in aquatic systems $[6,19]$. The absorption coefficient $a_{\text {CDOM }}(350)$ is used as a proxy for charactering CDOM concentration [7, 26]. SUVA $_{254}$ values have been proven to have a correlation with DOM aromaticity as determined by ${ }^{13} \mathrm{C}-\mathrm{NMR}$ [27-28]. Previous studies have shown that SUVA $_{254}$ values are always comparable to hydrophobic organic acid fraction (HPOA), thus indicating the source of organic matter in aquatic systems. High $\mathrm{SUVA}_{254}$ values indicate that $\mathrm{CDOM}$ has allochthonous sources with significant vascular plant inputs $[22,28]$. On the contrary, low SUVA $_{254}$ values indicate that autochthonous sources (algal or microbial degradation) dominate the organic matter content with little vascular plant input $[27,29]$. The ratio of spectral slopes $S_{\mathrm{R}}$ is also an indicator of CDOM molecular weight (MW) and source [26, 28, 30]. Previous studies have reported that $S_{\mathrm{R}}$ values are inversely proportional to CDOM MW (molecular weight), and a steeper spectral slope signifies decreasing aromatic content and vice versa [31].

All the optical parameters used to illustrate the spectral properties of CDOM are shown in Table 1 . 
Table 2. Average values of CDOM absorption parameters and $s$ in different seasons in all samples.

\begin{tabular}{|c|c|c|c|c|c|}
\hline Time & $N$ & $\alpha(254) \mathrm{m}^{-1}$ & $\alpha(350) \mathrm{m}^{-1}$ & $S_{\mathrm{R}}$ & SUVA $_{254}$ \\
\hline May 2016 & 17 & 26.34 & 4.311 .04 & 0.880 .11 & 1.740 .75 \\
\hline August 2016 & 17 & 25.805 .66 & 4.50 & 1.100 .39 & 0.920 .36 \\
\hline November2016 & 17 & 15.956 .79 & 3.461 .52 & 1.510 .60 & 1.170 .73 \\
\hline All & 51 & 22.707 .61 & 4.091 .45 & 1.160 .49 & 1.280 .73 \\
\hline
\end{tabular}

CDOM in May exhibited higher average molecular weight due to the lowest $S_{\mathrm{R}}$ and highest $\alpha_{\mathrm{CDOM}}(254)$ and SUVA $_{254}$ values. This suggested a relatively weak microbial decomposition of phytoplankton and more allochthonous substances with high aromatic content in May. The mean $\alpha_{\text {CDOM }}(350)$ for water samples in May, August, and November were $4.31 \pm 1.04 \mathrm{~m}^{-1}, 4.50 \pm 1.5 \mathrm{~m}^{-1}$, and $3.46 \pm 1.52 \mathrm{~m}^{-1}$ (Tab. 2), respectively. The difference in these parameters was likely related to temporal variations exerting influence on uncertain hydrological, climatic, and terrestrial inputs as well as surface runoff variations [3].

\section{EEM-PARAFAC Components of CDOM}

Four fluorescent components were identified by PARAFAC in the 51 river samples. The excitation and emission loadings of the fluorescence components identified by EEM-PARAFAC are summarised in Fig. 2 and Table 3. The first fluorescent component (C1) was consistent with the terrestrial humic-like peaks and was defined by peaks at $230 \mathrm{~nm}$ excitation and $344 \mathrm{~nm}$ emission wavelengths. Previous studies have shown that this component is derived from terrestrial plants or soil organic compounds [32]. The second fluorescent component (C2) was an autochthonous tryptophan-like substance with two excitation maxima (235 nm and $280 \mathrm{~nm})$ at a single emission wavelength $(355 \mathrm{~nm})$, which was consistent with protein-like peaks $\mathrm{T}$ and resembled tryptophan-like fluorescence detected in many different aquatic environments [33-35]. Component (C3) exhibited two excitation maxima ( $255 \mathrm{~nm}$ and $270 \mathrm{~nm}$ ) and one emission maximum (470 nm), which was similar to humic-like substances from terrestrial origin CDOM inputs. The spectral features were also similar to other reported terrestrial components from agricultural catchments such as soil organic matter and urban wastewater [36-37]. Component C4 was composed of one peak with excitation maximum at $245 \mathrm{~nm}$ and emission peak centred at $490 \mathrm{~nm}$, and was likely related to humic-like component A [38]. These fluorescence characteristics were associated with terrestrial organic matter that was composed of large molecular weight aromatic organic compounds [39-41].

Compared to humic-like components, protein-like fluorescence components are more likely to be used by microbes as an energy source. Therefore, proteinlike fluorescence components are generally used as an indicator of organic pollution [42-43] derived from anthropogenic activities. Terrestrial humic-like components were a mixture of the humic-like acids of aromatic and aliphatic compounds, while aquatic humic-like substances originated from phytoplankton. Protein-like components mainly consist of dissolved amino acids such as tryptophan-like substances.

Table 3. Spectral characteristics of excitation and emission maxima of the four fluorescent components identified by PARAFAC modelling for the entire EEMs data set and their comparison with previously identified sources.

\begin{tabular}{|c|c|c|c|c|c|}
\hline $\begin{array}{c}\text { Fluorescent } \\
\text { component }\end{array}$ & $\mathrm{Ex}_{\max }$ & $\mathrm{Em}_{\max }$ & Description and probable source & $\begin{array}{c}\text { Coble } \\
(1996)\end{array}$ & Reference \\
\hline $\mathrm{C} 1$ & 245 & 440 & $\begin{array}{c}\text { Terrestrial humic substances. Fulvic acid fluorophore group. } \\
\text { DOM exported from agricultural catchments. Widespreadly. }\end{array}$ & $\mathrm{A}$ & $\begin{array}{c}\mathrm{C} 4 \leq 250(360) / 440[44] \\
\mathrm{C} 1 \leq 250 / 448[44]\end{array}$ \\
\hline $\mathrm{C} 2$ & $\begin{array}{c}235 \\
(280)\end{array}$ & 355 & $\begin{array}{c}\text { Tryptophan-like fluorescence. Amino acids free or bound } \\
\text { in proteins. Correlated to terrestrial fluorescent material in } \\
\text { forested catchments or anthropogenic input. }\end{array}$ & $\mathrm{T}$ & $\begin{array}{c}\mathrm{C} 7=280 / 344[44] \\
\mathrm{C} 1=230 / 344[35]\end{array}$ \\
\hline $\mathrm{C} 3$ & 270 & 470 & $\begin{array}{c}\text { Terrestrial humic substances. Dominating the DOM export- } \\
\text { ed from the natural catchments during the warmer months } \\
\text { of the year. Also exported from agricultural } \\
\text { catchments by the soil organic matter and urban wastewater. }\end{array}$ & A and C & $\begin{array}{c}\text { C2 } 2=270(370) / 460[37] \\
\mathrm{C} 3=250(355) / 461[35]\end{array}$ \\
\hline $\mathrm{C} 4$ & 245 & 490 & Terrestrial humic substances, widespread & $\mathrm{A}$ & $\begin{array}{c}\mathrm{C} 4=280(400) / 480[41] \\
\mathrm{C} 1=255(350) / 471[4]\end{array}$ \\
\hline
\end{tabular}

This component was characterized as a mixture of the traditional terrestrial humic-like peaks $\mathrm{A}$ and $\mathrm{C}$, protein-like peaks $\mathrm{T}$ according to Coble (1996) [38] 

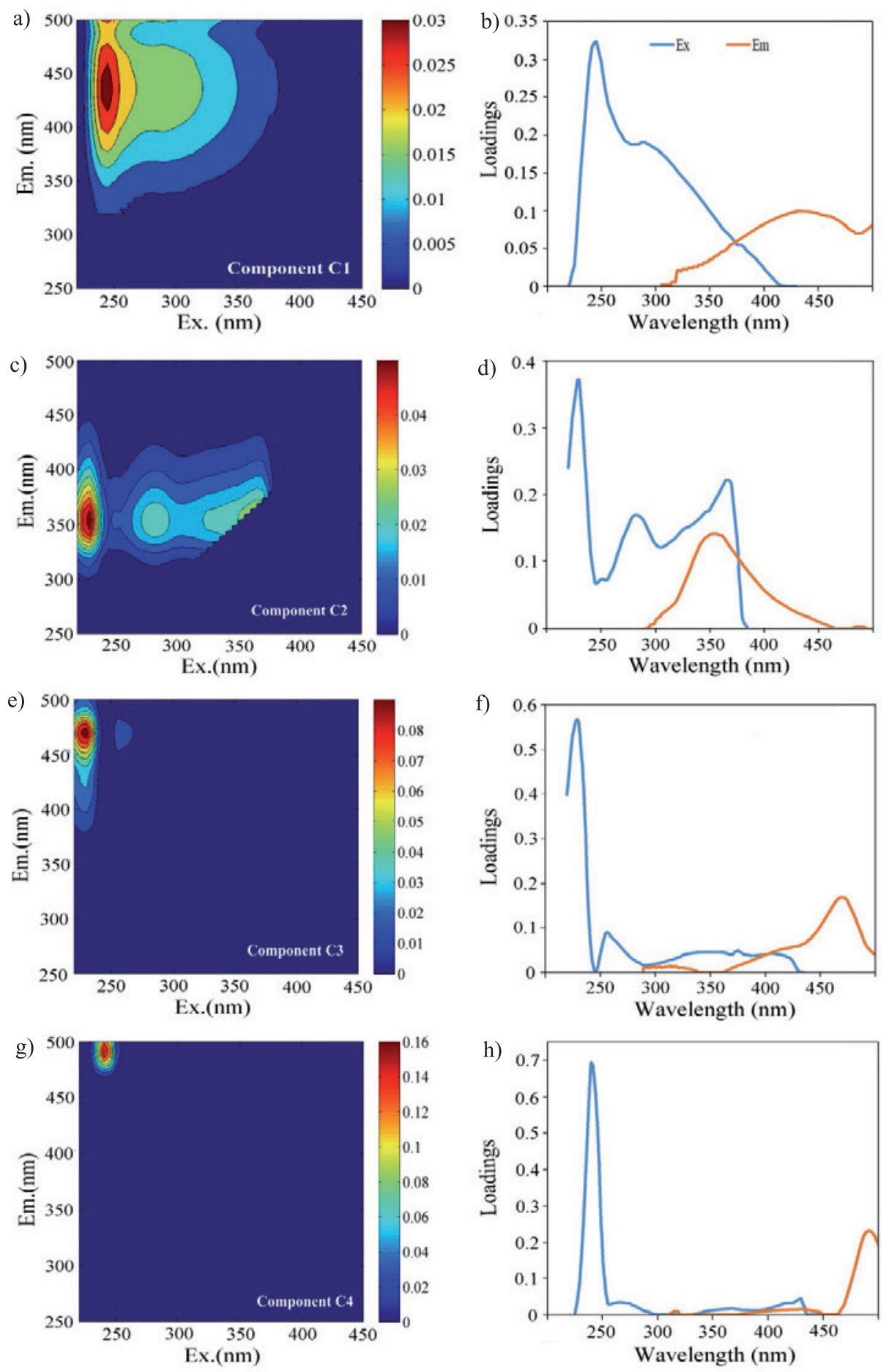

Fig. 2. PARAFAC modelling output showing fluorescence signatures of the four components (a) (c) e), and g)) and line plots with excitation (blue) and emission (red) loadings (b) d) f), and h)) of each fluorescent component (Raman: $\mathrm{nm}^{-1}$ ).

\section{Temporal Distribution of PARAFAC Components}

The riverine samples had similar geological, hydrological, and climatic settings for both Yinma and Yitong rivers. It was presumed that when the CDOM components are under the control of different environmental factors, then CDOM sources and components associated with DOC concentrations generally show seasonal variations. Therefore, the water samples from different sites for each season were pooled together to study the seasonal variation of the maximum fluorescence intensities $\left(F_{\max }\right)$. The mean fluorescence intensity for each PARAFAC component was $11.73 \mathrm{~nm}^{-1}$. The corresponding intensities of $\mathrm{C} 1$, C2, C3, and C4 were $8.28 \mathrm{~nm}^{-1}, 8.19 \mathrm{~nm}^{-1}, 12.09 \mathrm{~nm}^{-1}$, and $18.33 \mathrm{~nm}^{-1}$, respectively (Fig. 3a). The tryptophanlike component, $\mathrm{C} 2$, accounted for the lowest $(17.5 \%)$ proportion of the total fluorescence intensities. 
a)

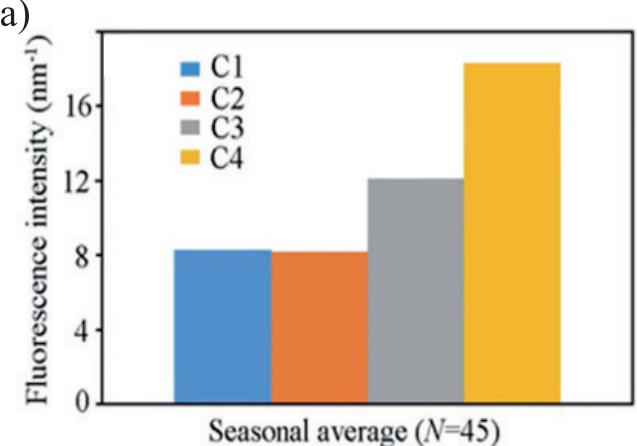

c)

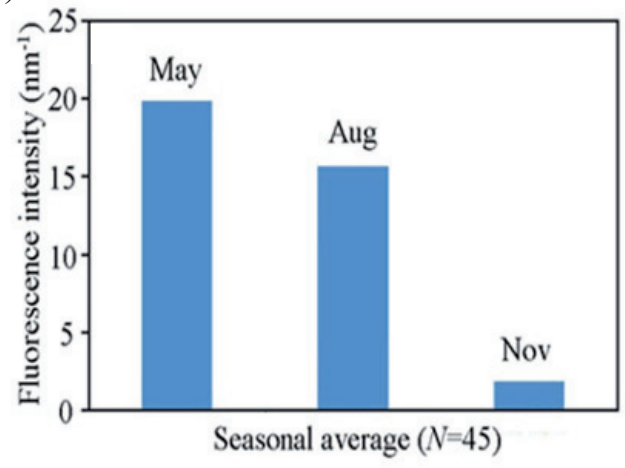

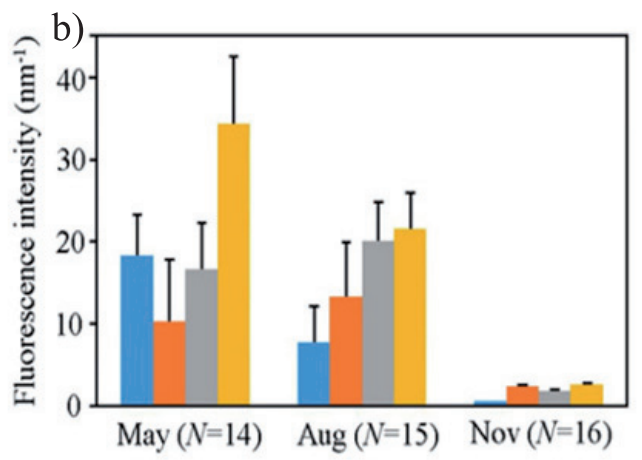

d)

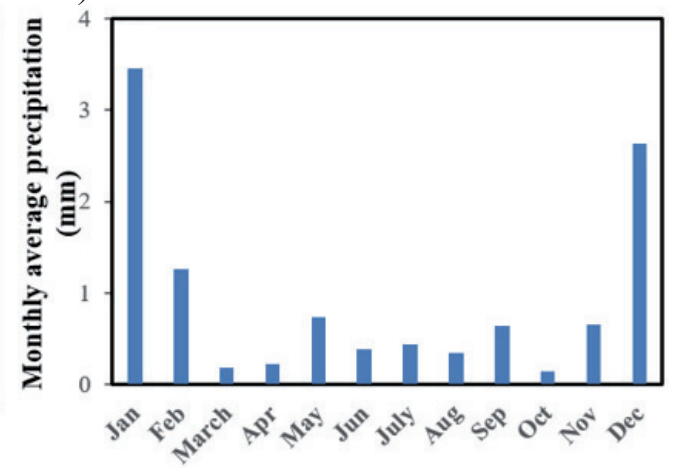

Fig. 3. Fluorescence intensities of $F_{\max }$ for the humic-like components (C1, C3, and C4) and the tryptophan-like component (C2) in water samples from the Yinma River from May to November 2016: a) seasonal average of $F_{\max }$ for EEM-PARAFAC components, b) seasonal variation of the four EEM-PARAFAC components, c) seasonal variation of total fluorescence, and d) monthly average precipitation at Changchun Station located at the Yinma and Yitong watershed.

$\mathrm{C} 3$ and $\mathrm{C} 4$ dominated the fluorescence intensity and $\mathrm{C} 4$ exhibited the highest fluorescence intensity proportion at $39.1 \%$. This indicates that most of the CDOM in rivers originated from terrestrial humic substances, especially soil organic matter and urban wastewater from agricultural catchments, as well as natural catchments during the warmer months.

As shown in Figure 3b, the average $F_{\max }$ of the four components showed seasonal variations. In November, the intensities of the four fluorescent components C1 $\left(0.54 \mathrm{~nm}^{-1}\right), \mathrm{C} 2\left(2.33 \mathrm{~nm}^{-1}\right), \mathrm{C} 3\left(1.81 \mathrm{~nm}^{-1}\right)$, and C4 $\left(2.58 \mathrm{~nm}^{-1}\right)$ - showed lower values in comparison to May and August. The fluorescence intensity of the proteinlike components, $\mathrm{C} 2$, was similar to $\mathrm{C} 4$ and showed higher values than $\mathrm{C} 1$ and $\mathrm{C} 3$. It could be attributed to a low biological activity due to low temperatures [46]. Additionally, organic matter from agricultural soil and urban wastewater also decreased in winter (November). From May to August, with a gradual decrease in precipitation, the intensities of $\mathrm{C} 1$ and $\mathrm{C} 4$ fluorescence components decreased and the intensities of $\mathrm{C} 2$ and C3 fluorescence components increased. This result may relate to concentrated rainfall events, resulting in a flood in May (Fig. 3d). This process increased the intensities of $\mathrm{C} 1$ and $\mathrm{C} 4$ components due to increased amounts of terrestrial inputs by rainfall erosion and sediment re-suspension. Likewise, previous studies have found that rainwater CDOM for this study was largely characterised by protein-like components $[10$,
47], indicating that the frequency of rainfall and runoff could significantly impact the quantity and quality of CDOM collected from the catchment. Particularly C3 in the CDOM was associated with anthropogenic activities resulting from agricultural catchments. The increase of urban wastewater showed an gradually increased and relatively weak microbial decomposition of plants during the warmer year of month from $16.58 \mathrm{~nm}^{-1}$ (May) to $20.39 \mathrm{~nm}^{-1}$ (August), which can be attributed to urban wastewater accounting for a certain proportion of the river water.

\section{Relationship of EEMS-PARAFAC-Extracted Components and Water Quality}

When the 51 water samples were pooled together, there was a positive linear correlation between components $\mathrm{C} 3$ and $\mathrm{C} 4(R=0.86, p<0.001)$ and the components $\mathrm{C} 1$ and $\mathrm{C} 4(R=0.85, p<0.001)$ (Fig. 4). $\mathrm{C} 1$ represents the DOM exported from agricultural catchments and $\mathrm{C} 3$ was from agricultural catchments by the soil organic matter and urban wastewater, which were shown to result from the same terrestrial humic substances [4]. However, there was almost a weak correlation between the humic-like and proteinlike components as indicated by a relationship between component $\mathrm{C} 2$ and the other three components, thus, indicating that they had a different source. For all the water samples, there was no correlation between DOC 


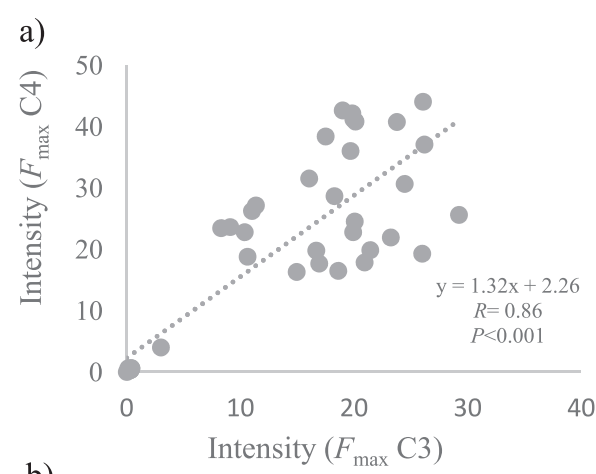

b)

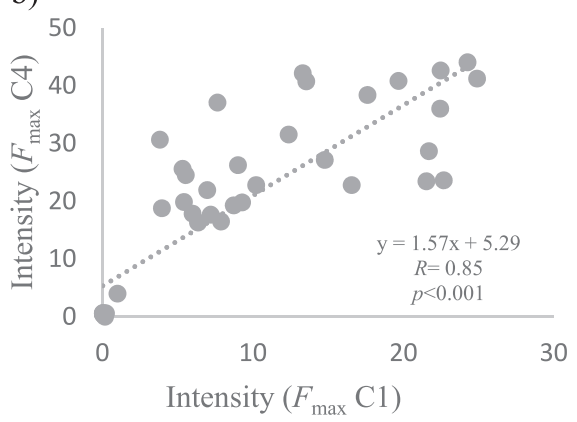

Fig. 4. Correlations between a) fluorescence intensities of the humic-like $F_{\max }(\mathrm{C} 3)$ and $F_{\text {max }}(\mathrm{C} 4)$, and b) fluorescence intensities of the humic-like $F_{\text {max }}(\mathrm{C} 1)$ and $F_{\text {max }}(\mathrm{C} 4)$.

and CDOM fluorescence. The linkage of a fluorescence signal to DOC was very complicated because of the impact of environmental factors, i.e., rainfall, algal blooms, and ice cover, which are known to affect the DOC concentrations [10]. It is important to note that there was no obvious positive correlation between Chl-a and EEM-PARAFAC-extracted components. Chl-a showed relatively weak negative relationships with component $\mathrm{Cl}(R=-0.48, p<0.001 ; N=45)$, C3 $(R=-0.41, p<0.001 ; N=45)$ and $\mathrm{C} 4(R=-0.50, p<0.001$; $N=45$ ). On one hand, more terrestrial inputs bring more nutrients and suspended particles, thus promoting algal growth, while on the other hand, more particles could also limit the transmission distance of light. The negative correlations demonstrated that the latter played a more significant role [21].

The significant correlation between fluorescence components and water quality parameters indicated a common control factor for the components and the concentration of the selected parameters in these polluted rivers. In May and August, the tryptophanlike fluorescent component $\mathrm{C} 2$ was significantly positively correlated with nutrients, e.g., TN (May, $R=0.83$; August, $R=0.84, p<0.001$ ), and there was weak correlation between fluorescent component $\mathrm{C} 2$ and TN in November $(R=0.35, \mathrm{p}<0.001)$ (Fig. 5a and Table 4). A significant positive correlation was found between TP and the component $\mathrm{C} 2(R=0.85, p<0.001)$ and $\mathrm{TP}$ and the component $\mathrm{C} 1(\mathrm{R}=0.75, p<0.001)$ in August (Fig. 5b and Table 4). Land use and land cover change has a great impact on water quality. TN and TP with positive loading on fluorescence components
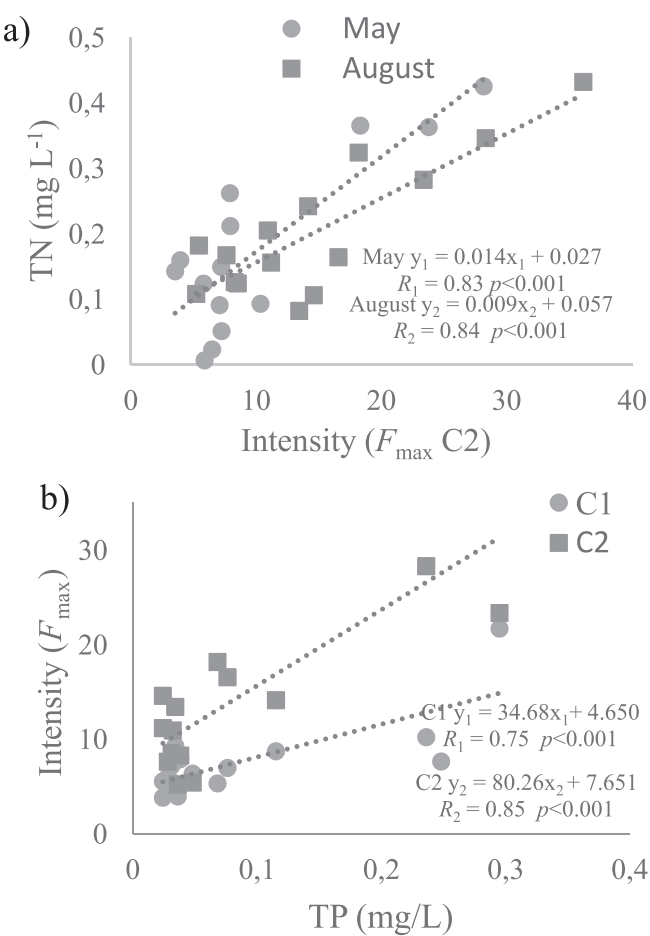

c)
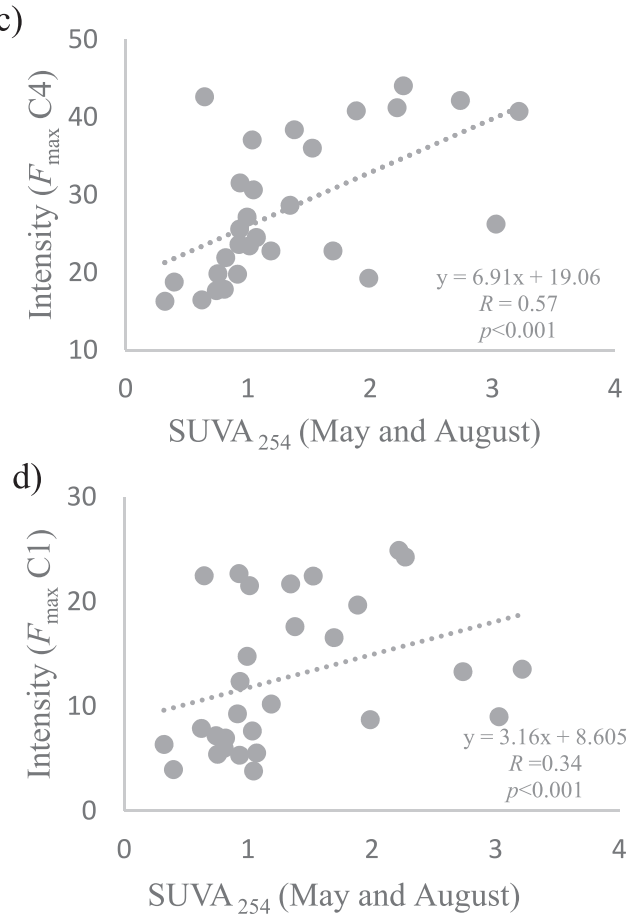

Fig. 5. Correlations between a) fluorescence intensities of the humic-like $F_{\max }$ (C1) and TN in May and August 2016; b) fluorescence intensities of the humic-like $F_{\max }(\mathrm{C} 1)$, proteinlike $F_{\text {max }}(\mathrm{C} 2)$, and TP in August 2016; c) $F_{\text {max }}(\mathrm{C} 4)$ and $\mathrm{SUVA}_{254}$ in May and August 2016; and d) $F_{\max }(\mathrm{C} 3)$ and $\mathrm{SUVA}_{254}$ in May and August 2016 (the unit of SUVA ${ }_{254}$ is nm.L/mg).

may be related to anthropogenic nutrient disturbances [28]. These results indicate that rainfall events bring more terrestrial nutrients in May and August than in November. Additionally, chemical fertiliser and pesticide were widely used by farmers in May and August, which were transported to the river with rainfall. 
Table 4. Correlation coefficients $(R)$ and significance levels $(p)$ of the linear relationships between CDOM absorption, dissolved organic carbon (DOC), total nitrogen (TN), total phosphorous (TP), ammonia-N $\left(\mathrm{NH}_{3}-\mathrm{N}\right)$, and fluorescent components.

\begin{tabular}{|c|c|c|c|c|c|}
\hline Seasons & Component & $a(254) \mathrm{m}^{-1}$ & DOC $\mathrm{mg} \mathrm{L}^{-1}$ & $\mathrm{TN} \mathrm{mg} \mathrm{L}^{-1}$ & $\mathrm{TP} \mathrm{mg} \mathrm{L}^{-1}$ \\
\hline \multirow{4}{*}{ May } & $\mathrm{C} 1$ & $0.34^{*}$ & - & $0.30^{*}$ & $0.36^{*}$ \\
\hline & $\mathrm{C} 2$ & - & - & $0.83^{*}$ & - \\
\hline & $\mathrm{C} 3$ & - & $0.56^{*}$ & - & $0.49^{*}$ \\
\hline & $\mathrm{C} 4$ & - & $0.42^{*}$ & - & $0.60^{*}$ \\
\hline \multirow{4}{*}{ August } & $\mathrm{C} 1$ & - & - & - & $0.75^{* *}$ \\
\hline & $\mathrm{C} 2$ & - & - & $0.84^{*}$ & $0.85^{*}$ \\
\hline & $\mathrm{C} 3$ & $0.52^{*}$ & - & $0.48^{*}$ & - \\
\hline & $\mathrm{C} 4$ & - & - & $0.36^{*}$ & - \\
\hline \multirow{4}{*}{ November } & $\mathrm{C} 1$ & - & - & - & - \\
\hline & $\mathrm{C} 2$ & $0.58^{*}$ & $0.39^{*}$ & $0.35^{*}$ & $0.40^{*}$ \\
\hline & $\mathrm{C} 3$ & - & - & - & - \\
\hline & $\mathrm{C} 4$ & $0.34^{*}$ & - & $0.53^{*}$ & - \\
\hline
\end{tabular}

${ }^{*} p<0.05$ level; ** $p<0.001$ level

In November, $\mathrm{C} 2$ was derived from the terrestrial macromolecule structures of protein-like substances. A weak relationship was found between components $\mathrm{C} 3$ and DOC $(R=0.56, p<0.001)$ in May, likely from the decay of plants through microbial activity or from contamination of human and animal waste. No obvious correlations were found between DOC and CDOM fluorescence components. This was likely related to uncoloured DOC from terrestrial fluorescent materials in forested catchments or anthropogenic inputs, and these accounted for high concentrations of CDOM. Brezonik et al. [48] reported that DOC from anthropogenic sources (e.g., wastewater effluent) was generally uncoloured. However, in this study it was found that component C3 associated with agricultural catchments and urban wastewater showed a correlation with DOC in May (Table 4). More rainfall events and precipitation occurring in May could bring more terrestrial DOM into rivers by rain splash erosion, loss of topsoil from slopes, and bottom of farm furrows (Fig. 3). In addition, this process also resulted in the entrance of $\mathrm{N}$ and $\mathrm{P}$ into surface runoff. The linkage of a fluorescence signal to DOC was very complicated because of the seasonal impact, and the river was seriously affected by point source pollution.

It is important to note that $\mathrm{C} 4$ associated with terrestrial humic substances presented correlation with $\mathrm{SUVA}_{254}(R=0.57, p<0.001)$, and $\mathrm{Cl}$ presented weak correlation with $\mathrm{SUVA}_{254}(R=0.34, p<0.001)$ in the samples collected from May and August (Figs. 5c) and $5 \mathrm{~d})$. This indicates that the sources showed a trend with the aromatic content of CDOM. These observations showed that DOC had a wide range of sources, and that the Yinma and Yitong rivers were significantly polluted by terrestrial and agriculture pollution.

\section{Conclusions}

In this study, the EEM-PARAFAC method and water quality parameters were used to characterise the fluorescent components in terms of seasonal variation as well as contamination sources for the Yinma and Yitong rivers in May, August, and November 2016. Three humic-like components $(\mathrm{C} 1, \mathrm{C} 3$, and $\mathrm{C} 4)$ and one protein-like component (C2) were identified using EEMPARAFAC. The three humic-like components originated from terrestrial inputs and the protein-like component originated from allochthonous and autochthonous substances. A linear correlation was observed between the two fluorescent components $\mathrm{C} 3$ and $\mathrm{C} 4$. The results indicate that the $\mathrm{C} 3$ and $\mathrm{C} 4$ components were controlled by common sources and similar removal processes. The drastic reduction in CDOM in winter (November) was mainly due to decreased biological or human activity. The seasonal variability of the results suggests that rainfall had more significant influence in May than in August. These results indicate that CDOM in the Yinma and Yitong Rivers originated mainly from the external input, which plays an important role in the characteristics of fluorescent components in CDOM. In this study, a significant correlation between CDOM and TP as well as TN substantiated that CDOM resulted from terrestrial pollution sources such as agriculture inputs. Additionally, the results indicate that CDOM is a key indicator of the TN and TP concentrations in water.

\section{Acknowledgements}

This study was financially supported by the National Major Program of Water Pollution Control 
and Treatment Technology of China under grant No. 2014ZX07201-011-002 (2014-2017).

\section{Conflict of Interest}

The authors declare no conflict of interest.

\section{References}

1. STEDMON C.A., MARKAGER S., KAA, H. Optical properties and signatures of chromophoric dissolved organic matter (CDOM) in Danish coastal waters. Estuarine, Coastal and Shelf Science. 51, 267, 2000.

2. SONG K.S., LI L., LENORE T., NICOLAS C., LI L.H., SHI K. Spectral characterization of colored dissolved organic matter (CDOM) for productive inland waters and its source analysis. Chinese Geographical Science. 25, 295, 2015.

3. SONG K.S., ZANG S.Y., ZHAO Y., LI L., DU J., ZHANG N.N., WANG X.D., SHAO T.T., GUAN Y., LIU, L. Spatiotemporal characterization of dissolved carbon for inland waters in semi-humid/semi-arid region, China. Hydrol Earth Syst. 17, 4269, 2013.

4. ZHANG Y.L., ZHANG E.L., YIN Y., VANDIJK M.A., FENG L.Q., SHI Z.Q., LIU M.L., QIN B.Q. Characteristics and sources of chromophoric dissolved organic matter in lakes of the Yungui Plateau, China, differing in trophic state and altitude. Limnol Oceanogr. 55, 2645, 2010.

5. XIE H., AUBRY C., ZHANG Y., SONG G. Chromophoric dissolved organic matter (CDOM) in first-year sea ice in the western Canadian Arctic, Mar. Chem. 165, 25, 2014.

6. HELMS J.R., STUBBINS A., RITCHIE J.D., MINOR E. C., KIEBER D.J., MOPPER K. Absorption spectral slopes and slope ratios as indicators of molecular weight, source, and photo bleaching of chromophoric dissolved organic matter. Limnology and Oceanography. 53, 955, 2008.

7. ZHANG Y.L., YIN Y., FENG L.Q., ZHU G.W., SHI Z.Q., LIU X.H., ZHANG Y.Z. Characterizing chromophoric dissolved organic matter in Lake Tianmuhu and its catchment basin using excitation-emission matrix fluorescence and parallel factor analysis. Water Research. 45, 5110, 2011.

8. BARKER J.D., KLASSEN J.L., SHARP M.J., FITZSIMONS S.J., TURNER R.J. Detecting biogeochemical activity in basal ice using fluorescence spectroscopy, Ann. Glaciol. 51, 47, 2010.

9. BARKER J.D., DUBNICK A., LYONS W.B., CHIN Y.P. Changes in Dissolved Organic Matter (DOM) Fluorescence in Proglacial Antarctic Streams. Arctic Antarctic and Alpine Research. 45, 305, 2013.

10. ZHAO Y., SONG K.S., WEN Z.D., LI L., ZANG S.Y., SHAO T.T., LI S.J., DU J. Seasonal characterization of CDOM for lakes in semiarid regions of Northeast China using excitation-emission matrix fluorescence and parallel factor analysis (EEM-PARAFAC). Biogeosciences Discussions. 13, 1635, 2016.

11. ZHANG Y.L., LIU X.H., OSBURN C.L., WANG M.Z., QIN B.Q., ZHOU Y.Q. Photo bleaching response of different Source of Chromophoric Dissolved Organic Matter Exposed to Natural Solar Radiation Using Absorption and Excitation-Emission Matrix Spectra. Plos One. 8, e77515, 2013.
12. YAO X., ZHANG Y.L., ZHU G.W., QIN B.Q., FENG L.Q., CAI L.L., GAO G. Resolving the variability of CDOM fluorescence to differentiate the sources and fate of DOM in Lake Taihu and its tributaries. Chemosphere. 82, 145, 2011.

13. ZHOU Y., JEPPESEN E., ZHANG Y.L., SHI K., LIU X.H., ZHOU G,W. Dissolved organic matter fluorescence at wavelength $275 / 342 \mathrm{~nm}$ as a key indicator for detection of point-source contamination in a large Chinese drinking water lake. Chemosphere. 144, 503, 2016.

14. LI S.J., CHEN Y. N., ZHANG J.Q., SONG K.S., MU G.Y., SUN C.Y., JU H.Y., JI M.C. The relationship of chromophoric dissolved organic matter parallel factor analysis fluorescence and polycyclic aromatic hydrocarbons in natural surface waters. Environ Sci Pollut Res. 1, 2017.

15. ZHANG F., LIU X.P., ZHANG J.Q., WU R.N., MA Q.Y., CHEN Y.N. Ecological vulnerability assessment based on multi-sources data and SD model in Yinma River Basin, China. Ecological Modelling. 349, 41, 2017.

16. SONG K.S., LI L., TEDESCO L.P., LI S., DUAN H.T., LIU D.W., HALL B.E., DU J., LI Z.C., SHI K., ZHAO Y. Remote estimation of chlorophyll a in turbid in land waters: three-band model vs. GA-PLS model, Remote Sens. Environ. 136, 342, 2013,

17. BABIN M., STRAMSKI D., FERRARI G. M., CLAUSTRE H., BRICAUD A., OBOLENSKY G., HOEPFFNER N. Variations in the light absorption coefficients of phytoplankton, nonalgal particles, and dissolved organic matter in coastal waters around Europe. Journal of Geophysical Research Oceans. 108, 32110, 2003.

18. ZHANG Y.L., QIN B.Q., ZHU G.W., ZHANG L., YANG L.Y. Chromophoric dissolved organic matter (CDOM) absorption characteristics in relation to fluorescence in Lake Taihu, China, a large shallow subtropical lake. Hydrobiologia. 581, 43, 2007.

19. JAFFÉ R., BOYER J.N., LU X., MAIE N., YANG C., SCULLY N.M., MOCK S. Source characterization of dissolved organic matter in subtropical mangrovedominated estuary by fluorescence analysis. Marine Chemistry. 84, 195, 2004.

20. STEDMON C.A., BRO R. Characterizing dissolved organic matter fluorescence with parallel factor analysis: a tutorial. Limnology and Oceanography Methods. 6, 572, 2008.

21. LI S.J., ZHANG J.Q., MU G.Y., JU H.Y., WANG R., LI D.J., ALI H. S. Spatiotemporal Characterization of Chromophoric Dissolved Organic Matter (CDOM) and CDOM-DOC Relationships for Highly-Polluted Rivers. Water. 8 (9), 399, 2016.

22. SPENCER R.G.M., BUTLER K.D., AIKEN G.R. Dissolved organic carbon and chromophoric dissolved organic matter properties of rivers in the USA. Journal of Geophysical Research. 117, G03011, 2012.

23. DEL CASTILlO C.E., GILBES F., COBLE P.G., MÜLLER-KARGER F.E. On the dispersal of riverine colored dissolved organic matter over the West Florida Shelf. Limnology and Oceanography. 45 (6), 1425, 2000.

24. WINTERDAHL M., ERLANDSSON M., FUTTER M.N., WEYHENMEYER G.A., BISHOP K. Intraannual variability of organic carbon concentrations in running waters: Drivers along a climatic gradient. Global Biogeochemical Cycles. 28 (4), 451, 2014.

25. LI S., ZHANG J., MU G., et al. Optical Properties of Chromophoric Dissolved Organic Matter in the Yinma 
River Watershed and Drinking Water Resource of Northeast China. Polish Journal of Environmental Studies. 25 (3), 2016.

26. ZHAO Y., SONG K.S., LI S.J., MA J.H., WEN Z.D. Characterization of CDOM from urban waters in NorthernNortheastern China using excitation-emission matrix fluorescence and parallel factor analysis. Environmental science and pollution research. 23 (15), 15381, 2016.

27. WEISHAAR J.L., AIKEN G.R., BERGAMASCHI B.A., FRAM M.S., FUJII R., MOPPER K. Evaluation of specific ultraviolet absorbance as an indicator of the chemical compositionand reactivity of dissolved organic carbon. Environmental Science and Technology. 37, 4702, 2003.

28. WEN Z.D., SONG K.S., ZHAO Y., DU J., MA J.H. Influence of environmental factors on spectral characteristics of chromophoric dissolved organic matter (CDOM) in Inner Mongolia Plateau, China. Hydrology and Earth System Sciences. 20 (2), 787, 2015.

29. SPENCER R.G.M., AIKEN G.R., WICKLAND K.P., STRIEGL R.G., HERNES P.J. Seasonal and spatial variability in dissolved organic matter quantity and composition from the Yukon River basin, Alaska. Global Biogeochemical Cycles. 22, 116, 2008.

30. SPENCER R.G.M., HERNES P.J., RUF R., BAKER A., DYDA R.Y., STUBBINS A., SIX J. Temporal controls on dissolved organic matter and lignin biogeochemistry in a pristine tropical river, Democratic Republic of Congo. Journal of Geophysical Research Biogeosciences. 115, 57, 2010.

31. GONNELLI M., VESTRI S., SANTINELLI C. Chromophoric dissolved organic matter and microbial enzymatic activity. A biophysical approach to understand the marine carbon cycle. Biophysical Chemistry. 182, 79, 2013.

32. FELLMAN J.B., HOOD E., SPENCER R.G.M. Fluorescence spectroscopy opens new windows into dissolved organic matter dynamics in freshwater ecosystems: a review. Limnology and Oceanogr. 55, 2452, 2010.

33. KOWALCZUK P., COOPER W.J., DURAKO M.J., KAHN A.E., GONSIOR M., YOUNG, H. Characterization of dissolved organic matter fluorescence in the South Atlantic Bight with use of PARAFAC model: Relationships between fluorescence and its components, absorption coefficients and organic carbon concentrations. Mar. Chem. 118, 22, 2010.

34. WILLIAMS C.J., YAMASHITA Y., WILSON H.F. Unraveling the role of land use and microbial activity in shaping dissolved organic matter characteristics in stream ecosystems. Limnology and Oceanogr. 55, 1159, 2010.

35. YAO X., ZHANG Y.L., ZHU G.W., QIN B.Q., FENG L.Q., CAI L.L., GAO G. Resolving the variability of CDOM fluorescence to differentiate the sources and fate of DOM in Lake Taihu and its tributaries. Chemosphere. 82, 145, 2011.
36. ZHAO Y., SONG K.S., WEN Z.D., FANG C., SHANG Y.X., LV L.L. Evaluation of CDOM sources and their links with water quality in the lakes of Northeast China using fluorescence spectroscopy. Journal of Hydrology. 550, 80, 2017.

37. SINGH S., D'SA E., SWENSON J. Seasonal variability in CDOM absorption and fluorescence properties in the Barataria Basin, Louisiana, USA. Journal of Environmental Sciences. 22, 1481, 2010.

38. COBLE P.G. Characterization of marine and terrestrial DOM in seawater using excitation-emission matrix spectroscopy. Mar Chem. 51, 325, 1996.

39. STEDMON C.A., MARKAGER S. Tracing the production and degradation of autochthonous fractions of dissolved organic matter by fluorescence analysis. Limnology and Oceanogr. 50, 1415, 2005a.

40. KOWALCZUK P., TILSTONE G.H., ZABŁOCKA M., RÖTTGERS R., THOMAS R. Composition of dissolved organic matter along an Atlantic meridional transect from fluorescence spectroscopy and parallel factor analysis. Mar Chem. 157, 170, 2013.

41. CUI H., SHI J.H., QIU L.L, ZHAO Y., WEI Z.M., WANG X.L., JIA L.M., LI J.M. Characterization of chromophoric dissolved organic matter and relationships among PARAFAC components and water quality parameters in Heilongjiang, China. Environmental Science and Pollution Research. 2, 10058, 2016.

42. BAKER A., INVERARITY R. Protein-like fluorescence intensity as a possible tool for determining river water quality. Hydrological Processes. 18, 2927, 2004.

43. HUR J., CHO J. Prediction of BOD, COD, and total nitrogen concentrations in a typical urban river using a fluorescence excitation-emission matrix with PARAFAC and UV absorption indices. Sensors. 12, 972, 2012.

44. STEDMON C.A., MARKAGER S. Resolving the variability in dissolved organic matter fluorescence in a temperate estuary and its catchment using PARAFAC analysis. Limnology and Oceanogr. 50 (2), 686, 2005.

45. MURPHY K.R., STEDMON C.A., WAITE T.S., RUIZ G.M. Distinguishing between terrestrial and autochthonous organic matter sources in marine environments using fluorescence spectroscopy. Mar Chem. 108, 40, 2008.

46. UUSIKIV J., VAHATAL A.V., GRANSKOG M.A., SOMMARUGA R. Contribution of mycosporine-like amino acids and colored dissolved and particulate matter to sea ice optical properties and ultraviolet attenuation. Limnology and Oceanogr. 55, 703, 2010.

47. CHENG Y.Y., GUO W.D., LONG A.M., CHEN S.Y. Study on optical characteristic of chromophoric dissolved organic matter in rainwater by fluorescence excitation-emission matrix and absorbance spectroscope. Spectroscopy and Spectral Analysis. 30, 2413, 2010

48. BREZONIK P.L., OLMANSON L.G., FINLAY J.C., BAUER M.E. Factors affecting the measurement of CDOM by remote sensing of optically complex inland waters. Remote Sensing of Environment. 157, 199, 2015. 